\title{
Correction to: Is drawing after learning effective for metacognitive monitoring only when supported by spatial scaffolds?
}

\author{
Julia Kollmer ${ }^{1} \cdot$ Katrin Schleinschok $^{2,3} \cdot$ Katharina Scheiter $^{2,3} \cdot$ Alexander Eitel $^{4}$
}

Published online: 22 October 2021

(c) The Author(s) 2021

\section{Correction to: Instructional Science (2020) 48:569-589 DOI 10.1007/s11251-020-09521-6}

The article "Is drawing after learning effective for metacognitive monitoring only when supported by spatial scaffolds?", written by Julia Kollmer · Katrin Schleinschok · Katharina Scheiter - Alexander Eitel., was originally published electronically on the publisher's internet portal on 10 July 2020 without open access. With the author(s)' decision to opt for Open Choice the copyright of the article changed on 22 July 2021 to (C) The Author(s) 2021 and the article is forthwith distributed under a Creative Commons Attribution 4.0 International License, which permits use, sharing, adaptation, distribution and reproduction in any medium or format, as long as you give appropriate credit to the original author(s) and the source, provide a link to the Creative Commons licence, and indicate if changes were made. The images or other third party material in this article are included in the article's Creative Commons licence, unless indicated otherwise in a credit line to the material. If material is not included in the article's Creative Commons licence and your intended use is not permitted by statutory regulation or exceeds the permitted use, you will need to obtain permission directly from the copyright holder. To view a copy of this licence, visit http:// creativecommons.org/licenses/by/4.0.

Publisher's Note Springer Nature remains neutral with regard to jurisdictional claims in published maps and institutional affiliations.

The original article can be found online at https://doi.org/10.1007/s11251-020-09521-6.

Julia Kollmer

julia.kollmer@psychologie.uni-freiburg.de

1 Department of Psychology, University of Freiburg, 79085 Freiburg, Germany

2 Leibniz-Institut für Wissensmedien, Tübingen, Germany

3 University of Tübingen, Tübingen, Germany

4 Justus-Liebig University, Giessen, Germany 